ideology and the values of their culture surely shows a false dichotomy. Indeed, what is an ethical code if not a reflection, a formal representation, of the values of a particular society? We do not practise medicine in a cultural vacuum; what is this absolute ethical code to which Rose refers? As the paper points out, the profession's attitudes to homosexuality, like all other issues, mirror those of society at large. The author clearly has her own ideological stance on issues of sexuality; perhaps the paper shows more of her position than that of the participants.

While the abstract exhorts us to treat HIV infection as purely a medical condition, the discussion describes the personal as well as the medical aspects of HIV infection and AIDS. Although these two seemingly opposing positions are represented in the paper, it is surely the latter that is the more complete account.

I believe that the paper deals with an important issue-that of prejudice and discrimination in our profession. It was published in a week in which homosexuality was very much in the news. This is not a reason, however, to publish a paper with such evident flaws; Rose's arguments would have been more appropriately presented in the personal view column.

Maindiff Court Hospital Abergavenny NP7 8NF

1 Rose L. Homophobia among doctors. BMF 1994;308:586-7. (26 February.)

\section{Guidelines for management of hypertension}

\section{Metabolic effects of drug treatment exaggerated}

EDITOR,-Recently, the World Health Organisation and International Society of Hypertension published guidelines on the management of mild hypertension. Peter $\mathbf{H}$ Winocour is concerned that these guidelines place too little emphasis on the impact of metabolic control on the management of essential hypertension. ${ }^{1} \mathrm{He}$ fears that treatment with diuretics and $\beta$ blockers as the first among equal agents of choice in the guidelines could lead to an 11-fold increase in the incidence of diabetes mellitus.

Two long term studies have described an increased incidence of diabetes mellitus in treated hypertensive patients. ${ }^{23}$ Both studies, however, compared hypertensive patients with an untreated healthy normotensive group. The results of both studies come as no surprise since the association between glucose intolerance and hypertension in untreated hypertensive patients has been well known for more than 70 years. Therefore, a higher incidence of diabetes mellitus would be expected in hypertensive patients compared with normotensive subjects. Hence, these data do not provide any evidence for a diabetogenic effect of diuretics and $\beta$ blockers in essential hypertension. ${ }^{23}$

On the contrary, in large cross sectional studies, as well as in prospective longitudinal studies such as the Framingham study and the San Antonio heart study, no differences were found in the prevalence or incidence of glucose intolerance and diabetes mellitus between hypertensive patients taking $\beta$ blockers and diuretics and hypertensive patients without treatment or taking other antihypertensive drugs.

In the treatment of mild hypertension studythe biggest long term trial comparing different antihypertensive agents-no differences were found between the $\beta$ blocker and diuretic groups and placebo or other antihypertensive agents with regard to fasting blood glucose concentration. ${ }^{4}$ In addition, when glucose intolerance or diabetes is already present prevention of potassium loss during low dose diuretic treatment and use of $\beta_{1}$ selective $\beta$ blockers prevents deterioration of glucose tolerance.

Hence, published evidence does not show any clinically relevant effects of $\beta_{1}$ selective $\beta$ blockers or low dose diuretics on glucose metabolism that would restrict their use as the first line antihypertensive drugs in either diabetic or non-diabetic hypertensive patients.

Department of Metabolic Diseases,

PETER T SAWICKI

University Clinic of Dusseldorf,

D-40225 Düsseldorf,

Germany

Winocour PH. Management of essential hypertension. $B M F$ 1994;308:470. (12 February.)

2 Skarfors ET, Lithell HO, Selenius I, Aberg H. Do antihypertensive drugs precipit

. Nystrơm $E$, et al. Do antihypertensive drugs precipitate Nystrom E, et al. Do antihyper
diabetes? $B M F$ 1984;289:1495-7.

Neaton JD, Grimm RH, Prineas RJ, Stamler J, Grandits GA, Neaton JD, Grimm RH, Prineas RJ, Stamler J, Grandits GA,
Elmer PJ, et al. Treatment of mild hypertension study. Final results. $f A M A$ 1993;270:713-24.

5 Sawicki PT, Mühlhauser I, Baba T, Berger M. Do angiotensin converting enzyme inhibitors represent a progress in hypertension care in diabetes mellitus? Diabetologia 1990;33:121-4.

\section{Sticking to guidelines can be expensive}

EDrTOR,-Gene Feder points out what has been clear for some time-that there are important differences between published guidelines for the treatment of hypertension. ${ }^{12}$ Feder also refers to the development of a "guidelines industry."

I have no objection to the creation of guidelines for minimal acceptable levels of medical care: indeed, I chaired the working party that prepared the British Hypertension Society's first report. ${ }^{3}$ The reasons for the diversity of guidelines are fairly obvious: evidence is inadequate and different people working in different health care systems do not always concur on all value judgments. Comprehensive documentation of a large literature with which most experts are depressingly familiar will not help them to agree on questions that they have been debating for years. Such a strategy will certainly favour the growth of a guidelines industry.

I have a more pressing concern, however, when expert guidelines are used to inform government decisions. Each national expert group producing advice works independently of developments in other fields of medicine. The impact of recommendations for funding these other fields is therefore ignored. Nevertheless, quite small differences in, for instance, the threshold pressure for drug treatment can have a massive effect on the eligible population and consequent expenditure. It is perhaps no coincidence that guidelines published in the United States, which has the highest expenditure on health care, also make the most radical recommendations for drug treatment while British recommendations are the most conservative. Even so, in Britain and many other countries only a minority of hypertensive patients are detected and only a minority of these are effectively treated. Effective optimal care therefore implies the prospect of a major increase in expenditure.

Under the circumstances only three outcomes seem possible. These are that guidelines continue to be ignored in practice; that expenditure in other areas not covered by guidelines is further reduced and that the overall budget is increased. The last would undoubtedly be the best outcome in the best of all possible worlds but also seems the most unlikely. It would be foolish to stand in the way of clinical effectiveness, but I wonder whether those who launch the guidelines industry appreciate its full implications.

Department of Medicine,

JD SWALES

University of Leicester,

Leicester Royal Infirmary,

Leicester LE2 7LX
Feder J. Management of mild hypertension. BMf 1994;308:470 (12 February.)

2 Swales JD. Guidelines on guidelines. I Hypertens 1993;11: 899-903.

3 Swales JD, Ramsay LE, Coope JR, Pocock SJ, Robertson JIS, Sever PS, et al. Treating mild hypertension. BMF 1989;298: 694-8.

\section{Insurance against injury in clinical trials}

\section{Urgent action needed but ...}

EDrToR,-I support the views expressed by Anne Ferguson ${ }^{1}$ and wish to enlarge on them. The East Berkshire Research Ethics Committee sought legal advice on the question of seeking indemnity, not only for the health authority which appoints us but also for the trust, when a locally generated study is to take place. This advice concurred with our view that an indemnity in the format agreed between the Department of Health and the Association of the British Pharmaceutical Industry should be provided for a locally generated study in the same way as it would be provided for a study sponsored by the manufacturer of a pharmaceutical product. This was thought to be particularly important when a drug was being studied for a purpose other than that for which it had been originally licensed. Experience shows that manufacturers are reluctant to offer indemnity under such circumstances even though they would stand to benefit financially if the work resulted in expanded use of their product.

The primary purpose of any research ethics committee must be to encourage ethically acceptable clinical research. I emphasise this not only as the chairman of a committee but also as a frequent participant in studies. It must come as a bitter disappointment to an applicant and an ethics committee when approval has to be withheld simply because no form of indemnity is offered, especially when the intended study is found to be not only sound but also potentially beneficial.

Unlike Anne Ferguson I do not envisage academics, clinical investigators, or for that matter NHS trusts being able to afford the insurance cover required in the absence of manufacturers' indemnity. It would be interesting to hear from other ethics committees, researchers, and health bodies how they have addressed these problems and whether they agree with my committee's view that urgent action by the Department of Health is required to ensure that valuable clinical research projects are not lost because of failure to resolve these issues.

exam Park Hospital, Slough SL $24 \mathrm{HL}$

1 Ferguson A. Clinical research in trust hospitals. BMf 1994;308: 412. (5 February.)

\section{.. . still no guidelines from Department of}

Health

EdrToR,-Early in 1993 the Department of Health, the Association of the British Pharmaceutical Industry, and a firm of solicitors representing the South West Regional Health Authority produced, after much discussion, an agreed form of indemnity for clinical studies. The department indicated that it would be issuing a guidance note for the benefit of health authorities, the note to be used in conjunction with the form of indemnity. Despite numerous letters from the association to the department, and many more telephone calls, the guidance note has still not been issued. Drafts which have been seen indicate that the document is entirely non-controversial. The difficulty with its non-appearance is that some health authorities are taking the view that the form of indemnity issued to them by companies is unofficial-that is, that it 
has not received the imprimatur of the Department of Health and will not until the guidance note has been issued. Clinical trials are thus being delayed to the disadvantage of both companies and patients. The association was encouraged to read in a letter from J S Metters that "The department will be issuing guidance on the use of a clinical trial indemnity form in due course." 1 As nothing had happened within two months of the letter being published, the association sent a letter to Dr Metters on 17 February asking when the guidance note was likely to be issued. On 28 February we received a reply stating that the letter was receiving attention.

The purpose of this letter is to indicate that there are patients in clinical trials who are possibly being denied proper compensation because the authority running the trial may not be properly indemnified. The delay in companies being able to carry out trials is also important. Further, professionals in health authorities should be aware that the association has done all in its power to ensure publication of the guidance note. The delay on the part of the department is inexcusable.

J P GRIFFIN Director

Association of the British Pharmaceutical Industry, London SW1A 2DY

1 Metters JS. Clinical research in trust hospitals. BMf 1993;307: 1499. (4 December.)

\section{Infection with hepatitis $C$ virus}

\section{New generation of assays should improve screening}

EDrToR,-A recent editorial discussed screening for hepatitis C virus infection. ${ }^{1}$ During the first eight months of screening for hepatitis $\mathrm{C}$ virus in the Oxford region 83177 units of blood (from 70700 donors) were tested with the Ortho second generation enzyme linked immunoassay. These reactions were repeatedly positive in $358(0.5 \%$ of all donors), and these were referred to the virology department for confirmation by the second generation recombinant immunoblot assay (RIBA-2, Ortho) and Murex BCJ11 enzyme linked immunoassay (with non-structural 5 and core antigens). Thirty nine samples $(0.05 \%$ of all donors) were confirmed to be positive, reacting in both additional tests; 243 were negative, reacting with neither test; and 76 were discrepant.

The samples with discrepant results were further analysed at Murex Diagnostics by western blotting (with non-structural 3, 4, and 5 and core antigens) and three further enzyme linked immunoassays (BHC28 with non-structural 3 and 5 and core antigens; BHC29 with non-structural 3, some 4 and 5 , and core components; and a core antigen assay). Twenty six of the samples were classified as positive, reacting with two or more of the additional immunoassays or with one immunoassay and at least one western blot antigen or with two western blot antigens; 13 were equivocal, reacting with only one additional immunoassay or one western blot antigen; and 37 were negative (table).

D Follett et al recommend subjecting samples with indeterminate results in the second generation recombinant immunoblot assay to nested reverse transcriptase/polymerase chain reaction analysis. ${ }^{2}$ We performed this on 74 of the specimens with discrepant results, using primers from the $5^{\prime}$ non-coding region. ${ }^{3}$ The results are included in the table.

$\mathrm{D}$ Li et at suggest that band intensity is important when considering indeterminant results in the second generation recombinant immunoblot assay. Of 54 such samples in our study, 13 (11 o which were reactive to core 22 antigen) showed a band intensity greater than $2+$. Eight (each reactive to c22) of these 13 were positive on furthe antibody analysis at Murex compared with eigh (also c22 reactive) of 41 with weaker bands $(\mathrm{P}=<0.05)$. Six (each $\mathrm{c} 22$ reactive and positive on further antibody testing) of the 13 with positive results in the polymerase chain raction compared with only two (each c22 reactive, one positive on further antibody analysis) of the 40 with weaker bands that were tested $(\mathbf{P}=<0.01)$. The positive predictive value of a c22 reactive immunoblot indeterminate result with a band intensity greate than $2+$ was $73 \%$ with respect to further antibody testing and $54 \%$ with respect to polymerase chain reaction analysis.

The advent of new generation immunoblot and enzyme linked immunoassays should help to resolve the problem of indeterminate results.

We thank the staff at the Oxford Regional Blood Transfusion Service, at the Virology Department, John Radcliffe Hospital, Oxford, and at Murex Diagnostics, Dartford, for their technical help.

Regional Virus Laboratory,

NICHOLAS HALLAM

City Hospital,

Edinburgh EH10 5SB

Virology Department,

Public Health Laboratory

John Radcliffe Hospital,

Oxford OX3 9DU

Oxford Regional Blood Transfusion Service, John Radcliffe Hospital,

Oxford OX3 9DU

Murex Diagnostics,

Dartford,

Kent DA1 5LR

1 Seymour CA. Asymptomatic infection with hepatitis C virus. $B M{ }^{7}$ 1994;308:670-71. (12 March.)

2 Follett EAC, Dow BC, McOmish F, Yap PL, Hughes W, Mitchell R, et al. HCV confirmatory testing of blood donors. Lancet 1991;338:1024.

3 Garson JA, Ring CJA, Tuke PW. Improvement of HCV genome detection with "short" PCR products. Lancet 1991;338: 1466-67.

4 Li XM, Reddy KR, Jeffers LJ, Parker T, de Medina M, Schrift ER. Indeterminate hepatitis C. Lancet 1993;341:835.

\section{Intravenous gammaglobulin may still infect patients}

EDIToR,-Transmission of hepatitis $\mathrm{C}$ virus has been shown in patients with common variable immunodeficiency receiving gammaglobulin replacement treatment. ${ }^{12}$ We have previously described the presence of antibodies to hepatitis $\mathrm{C}$ virus in commercial intravenous gammaglobulins. Although intravenous gammaglobulin prepared by a cold-ethanol fractionation procedure is regarded as safe, hepatitis $C$ virus $R$ NA has been detected in
Cohn fraction $\mathrm{II},{ }^{4}$ in the final product, and in a few batches of recently prepared intravenous gammaglobulin in France. ${ }^{5}$

We tested the hepatitis $C$ virus status of 51 patients with common variable immunodeficiency receiving intravenous gammaglobulin. Hepatitis $\mathbf{C}$ virus RNA (detected by nested polymerase chain reaction) was repeatedly found in 12 patients. This prevalence is much higher than that expected in the Italian population and suggests that hepatitis $C$ virus may have been transmitted by intravenous gammaglobulin. Twenty five patients were positive for antibodies to hepatitis $C$ virus on enzyme linked immunosorbent assay (ELISA), but these antibodies had probably been transmitted passively since most patients with common variable immunodeficiency do not produce detectable levels of specific antibodies.

We retested all our patients six months after an Italian law introduced (on 31 March 1993) mandatory screening for antibodies to hepatitis C virus of all donations from which intravenous gammaglobulin is prepared. We found 10 patients to be still positive for the antibody. We also tested three brands of intravenous gammaglobulin: five of six batches of brand $A$, one of four batches of brand $B$, and none of three batches of brand $C$ were positive for antibody on ELISA and second generation recombinant immunoblot assay (Ortho Diagnostic System). Hepatitis C virus RNA was not detected by polymerase chain reaction in two batches of brand $\mathrm{A}$ that were positive for antibody to hepatitis $\mathrm{C}$ virus, but the use of the polymerase chain reaction in screening intravenous gammaglobulin remains to be validated.

One patient with common variable immunodeficiency was tested in March 1993 and found to be negative for hepatitis $C$ virus with the polymerase chain reaction and on testing for antibodies to the virus. In July he developed acute hepatitis, with increased levels of alanine aminotransferase; hepatitis C virus RNA was detected. Between March and July he had not been exposed to any known risk factor for hepatitis $C$, but he did receive intravenous gammaglobulin (brand $\mathrm{A}$ ). Although intravenous gammaglobulins are strongly suspected to have transmitted hepatitis C virus in this and other patients with common variable immunodeficiency, formal evidence will require additional investigations. In the meantime, our data show that, despite the regulations, some batches of commercially available intravenous gammaglobulin are still positive for antibody to hepatitis $C$ virus and may be responsible for transmitting the virus. We support the enforcement of the guidelines for testing individual blood units by companies and for government controls.

I QUINTI

G SACCO D EL SALMAN R PAGANELII M FIORILII

FAIUTI

Department of Allergy and Clinical Immunology, La Sapienza University of Rome

Rome, Italy

Chair of Metodologia Clinica,

Catholic University of Rome,

Rome, Italy
Results of further analysis of 76 samples with discrepant results on second generation recombinant immunoblot assay (RIBA-2) and Murex BCH11 enzyme linked immunoassay

\begin{tabular}{|c|c|c|c|c|c|}
\hline \multirow[b]{2}{*}{ Discrepant result } & \multicolumn{3}{|c|}{ Final classification } & \multicolumn{2}{|c|}{$\begin{array}{l}\text { Reverse transcriptase/ } \\
\text { polymerase chain reaction }\end{array}$} \\
\hline & Positive & Equivocal & Negative & Positive & Negative \\
\hline BCH1 1 positive, RIBA-2 negative $(n=20)$ & 9 & 7 & 4 & 2 & 17 \\
\hline BHC11 positive, RIBA-2 indeterminate $(n=10) \dagger$ & 8 & 2 & 0 & 7 & 3 \\
\hline BHC11 negative, RIBA-2 indeterminate $(n=44) \ddagger$ & 8 & 4 & 32 & 1 & 42 \\
\hline BHC11 negative, RIBA-2 positive $(n=2)$ & 1 & 0 & 1 & 0 & 2 \\
\hline Total & 26 & 13 & 37 & 10 & 64 \\
\hline
\end{tabular}

ॠTwo samples were not tested. $†$ All reactive to $c 22$. $\$$ Twenty four reactive to $c 22,13$ to $c 1001 / 3$, seven to $c 33$.
1 Lane R. Non-A non-B hepatitis from intravenous gammaglobulin. Lancet 1983;ii:974-5.

2 Björkander J, Cunningham-Rundles C, Lundin P, Olsson R, Söderström R, Hanson LA. Intravenous immunoglobulin prophylaxis causing liver damage in 16 of 77 patients with prophylaxis causing liver damage in 16 of 77 patients with
hypogammaglobulinemia or IgG subclass deficiency. $A m \mathcal{F}$ hypogammaglobuline

3. Quinti I, Paganelli R, Scala E, Guerra E, Mezzaroma I, d'Offizi $\mathrm{GP}$, et al. Hepatitis $\mathrm{C}$ virus antibodies in gammaglobulin. Lancet 1990;336:1377.

4 Yei S, Yu MW, Tankersley DL. Partitioning of hepatitis C virus during Cohn-Oncley fractionation of plasma. Transfusion 1992;32:824-8.

5 Lefrère JJ, Mariotti $M$, Trepo C, Li JS, Lunel F, Frangeul L, et al. Testing for HCV-RNA in commercial intravenous immunoglobulins. Lancet 1993;341:834-5. 